\title{
REPORTS
}

\section{Folklore Research Resources in East European Studies: The Library and Archives of the American Hungarian Foundation}

\author{
Judit Hajnal Ward \\ Rutgers University \\ New Jersey, U.S.A. \\ Sylvia Csürös Clark \\ St. John's University \\ New York, U.S.A.
}

Resources for researching the folklore of immigrant groups vary from culture to culture. Hungarian Americans constitute several generations of immigrants who arrived in different waves. Their history of immigration shows strong similarities to that of many other ethnic groups from East Europe and their reasons for leaving can be attributed to the turmoil in the region in the late nineteenth and in the twentieth centuries. Folklore parallels to other ethnic groups have yet to be defined by scholars. A unique source for research in the area of folklore is the Library and Archives of the American Hungarian Foundation and it is a resource that can be used by folklorists and other scholars in many fields, not just by those interested in Hungarian Studies.

\section{Effects of the revolution in information access on research}

The rapid changes in information access and communication created new paths for research, publication, and scholarly communication. Subject guides on the homepages of academic libraries offer detailed descriptions of the collections themselves and of access policy. They have been created to assist scholars in deciding whether to access a resource electronically from a remote research location or to plan a trip and conduct research on site. Researchers increasingly need collection descriptions, guides, and finding aids to keep focused, to map out new directions for their research, and to be able to find and retrieve all relevant data. Browsing or searching large aggregated vendors' databases on any topic helps in locating full-text articles, bibliographic records, or just new research ideas. Popular search engines geared toward the academic community, such as Google Scholar among others, provide 
access to an incredible amount of material in all research fields, affording more visibility to traditional library and archive collections.

\section{Library collections related to Hungarian Studies in the United States}

Initiatives to preserve Hungarian heritage in the United States by fostering Hungarian ethnic collections in libraries, archives, museums, cultural and folklore centers have been successful to such an extent that it would be a heroic task to compile an organized list with detailed information about all Hungarian holdings. In the past decades, numerous electronic resources of differing value were added to serve the information needs of the research community. In addition to the noteworthy collection at the Library of Congress, a number of large academic libraries feature Hungarian collections. These include Columbia, Yale, Harvard, and Indiana universities. Significant Hungarian collections at public libraries should also be noted and include the New York Public Library and the Cleveland Public Library. Their collections have played a considerable role in the process of assimilation as well as in the construction and preservation of Hungarian identity [Kovács 1987: 248-260].

Comprehensive data on Hungarian collections in the United States have not been assembled to date and no exhaustive study of the vast resources that Hungarian collections contribute to research and scholarship has been published. In the 1990s, the National Széchényi Library (Budapest, Hungary) launched a survey to inventory Hungarian collections outside Hungary and managed to publish its inventories of Canada, Australia, and several Western European countries [Kovács and Faragó 1994]. Data on collections in the United States, however, were not published. The best data come from WorldCat, the global catalog covering libraries throughout the world as well as previous individual research studies, and these indicate that about 165 libraries in the United States have Hungarian collections.

A recent study resulted in the compilation of a comprehensive and up-to-date guide to Slavic and East European Collections in North America. It surveyed the libraries of nearly 90 institutions, and includes references to academic libraries with Hungarian collections [Urbanic and Feinberg 2004: 1-193].

\section{Hungarian ethnic collections in the United States}

Hungarian American libraries and holdings are considered an important type of ethnic resource outside the home country.(1) Generally 
speaking, ethnic collections evolve in response to a community's need for reading material in the mother tongue. Establishing and maintaining ethnic collections also reflects the efforts of the community to preserve cultural heritage and pass it on to future generations. Another important factor is the need in the community and the host society for materials to use in the teaching of the minority culture. The host community may also be motivated by a desire to conduct research on a particular community and its culture. As a result of these different needs, a variety of ethnic collections have been produced by the Hungarian American community and these complement those resources developed and maintained in American public and academic libraries. Although the two types of collections have their similarities, Hungarian ethnic libraries, those maintained by communities and individuals from the Hungarian American communities, do differ from collections maintained by large institutions. Community collections depend on individual initiative and partnerships within the community rather than on the American library system. The relationship between the community and the home country also plays a significant political and professional role. Finally, technical advancements, including access, communication, and transportation are also decisive [Kovács 2008].

Throughout history, wherever Hungarian communities have formed, library collections have evolved as one of the indicators of national identity. The earliest collections, those comprised of a couple hundred books, were established by Hungarian organizations. Societies, associations, religious communities, Hungarian houses and cultural centers were interested in serving the popular demand for reading material, and their number is estimated to roughly equal the number of organizations [Kovács 2008: 25-36]. Dependent on support from the members of the community and Hungarian resources, community collections suffered the attrition that was inevitable as the generation of Hungarian Americans they served advanced in age. Fragments of collections of this type were identified by Hungarian visiting Fulbright scholar Ilona Kovács from the ownership stamps in the library collection of the Bethlen Home, Ligonier, PA. This is a reference library which aims to document and preserve Hungarian heritage and came to house many of the early collections.

\section{Hungarian Americans and ethnic identity}

Hungarian Americans represent an immigrant group that has a history of cherishing and preserving its ethnic and cultural heritage. This 
phenomenon can be partly explained by the traditions established by a major wave of immigrants that arrived in the United States at the turn of the previous century. First-generation East-European immigrants who hoped to return had hardly any option other than to maintain their ethnic identification; for them it was an inescapable part of what they were [Gellén 1985: 25-35]. These immigrants, often classified more precisely as migrant workers, crossed the Atlantic Ocean with the sole purpose of making a decent income; they never intended to stay in the United States. Many of them returned to the home country permanently after a few years, while others traveled back and forth between the two countries several times. A significant proportion, however, never had the chance to return to their homeland. Political events and the economic situation in the twentieth century precluded any possibility of going back. Many of these immigrants, mostly peasants from rural Hungary, never relinquished their mother tongue, their national identity, or their desire to establish their own ethnic community [Degh 1966: 551-556]. Further hindered from returning by immigration laws and quotas in the United States and in Hungary, this first wave of Hungarian Americans found themselves in a situation that favored preservation of the inherited Hungarian culture.

New groups of carriers of traditional culture evolved both from the descendants of the first wave of immigrants and from new waves of arrivals from Hungary. Obviously, the American-born sons and daughters of Hungarian immigrants could not completely ignore the surrounding culture and quickly assimilated into American society. Many of them, however, became just as concerned with preserving and perpetuating their cultural heritage. Despite differences in their background, the drive to establish and promote Hungarian American communities, with or without the Hungarian language, has turned out to be a major part of their identity in the United States. Various local and transnational networks developed by ethnic institutions include churches, mutual aid societies, schools, and youth organizations.(2)

Religion was one significant factor in maintaining Hungarian heritage and identity. Hungarian churches were built at the beginning of the twentieth century and vibrant Hungarian communities bloomed around them, providing an opportunity to practice religion and cherish Hungarian culture. Churches also served as repositories of tradition and familiar ways of being [Tamas 1997: 615-634], while their publications, including bibles, song and prayer books, newspapers, bulletins and newsletters, documents on organizational and controversial religious 
topics, as well as more secular calendars and anniversary publications, played an important role in linking disconnected and geographicallyscattered imagined communities [Kovács 1998: 1868-1884].

\section{Hungarian Americans: Diversity and image}

The Hungarian American population of about 1.5 million is diverse and composed of immigrants and several generations of their descendants with various social, political, economic, and educational backgrounds.(3) Hungarians made their nation known in the United States as early as the time of the Revolution of 1848-1849, when the fight for independence and the declaration of Hungary's autonomy within the Habsburg Empire resonated well with the American Revolution. The first wave of immigrants at the end of 1849, called the Forty-Eighters, as well as Hungarian political leader Lajos Kossuth, were welcomed as exiles to the United States. Their presence contributed greatly to the favorable image that Americans have of Hungarians. Similar enthusiasm for Hungarian immigrants did not come again until a century later when Hungarians fleeing the failed anti-Soviet and antiCommunist Uprising of 1956 were given a hearty welcome. At that time about 40,000 so-called Fifty-Sixers, or Freedom-Fighters, settled in the United States. Greatly influenced by these two important waves of immigrants, the Hungarian American community has become a diverse and polarized group. As a result, the image and self-image of Hungarians has shifted back and forth between that of the "noble Hungarian" and the "Hunky" [Vardy 2001: 309-342]. Migrant workers, mainly impoverished and underprivileged Hungarian citizens who arrived in large numbers at the end of the nineteenth century and beginning of the twentieth century only to face the unknown, meaning the life of the industrial worker, were generally classed in the "Hunky" category, while those who fled repression in their homeland were considered noble. For both ends of the spectrum, preserving what they considered their cultural heritage, folklore, and language, as well as building ethnic communities to do so, served as a point of reference, a powerful tie to the homeland.(4) DPs (Displaced Persons) and various other interwar and postwar refugees, including famous scientists, were another important wave of immigrants. Some had difficulties assimilating; others did not, but all persistently conserved their Hungarian image.

This overview of Hungarian immigration serves to indicate some of the controversies within the Hungarian American community and points to the heroic efforts an organization must make to document various 
perspectives. The American Hungarian Foundation in New Brunswick, New Jersey has been successfully working to fulfill this mission for over 50 years, while also serving the academic research community interested in Hungarian and East European topics.

\section{The Hungarian community in New Jersey}

In addition to large Hungarian communities in Ohio, Louisiana, and California, New Jersey has traditionally had one of the largest Hungarian populations. A quick Google search on current Hungarian organizations in Central Jersey yields an assortment of organizations, such as the Hungarian Historical Society, American Hungarian Folklore Centrum, the Hungarian Folklore Museum in Passaic, the American Hungarian Museum in Teaneck, the Hungarian Boy Scouts Association in Garfield, and the Hungarian American Athletic Club in New Brunswick. Hungarian events in churches in Perth Amboy, Woodbridge, and New Brunswick also indicate efforts to preserve Hungarian culture. A Hungarian Festival with a rich folklore program is held in New Brunswick on the first Saturday of every June. New Brunswick, which attracted Hungarians by offering them employment around the turn of the last century at Johnson \& Johnson factories, has always been considered the center of the Hungarian community.(5) This role was further strengthened when, after the tragically-failed 1956 Hungarian Revolution, Camp Kilmer in Edison housed refugees from Hungary. At that point, the American Hungarian community proved its generosity and rushed to help the new arrivals. Rutgers, the State University of New Jersey, is one of the three North American institutions of higher education with a Hungarian degree program, supported in part by the Hungarian government since 1991. In this environment, the American Hungarian Foundation maintains the most significant Hungarian library collection in the United States.

\section{The Library and Archive of the American Hungarian Foundation (6)}

The American Hungarian Foundation was established in 1955 at Elmhurst College in Illinois as the American Hungarian Studies Foundation. Elmhurst College had a program of Hungarian Studies. As August J. Molnar, President of the Foundation remembers:

"The ideas that started the Foundation were not new, everybody was talking about doing all of those things and anybody who has any vision of the American-Hungarian community can see that this kind of effort has to be 
accomplished somehow if it's at all possible but simply how is it going to be done? We tried to do it." [Hajnal Ward and Csürös Clark 2009].

Modest as always, Professor August J. Molnar, a first generation American, drew upon the inspiration of his Professor at Elmhurst, Barnabás Dienes, to mastermind what became one of the most influential organizations in the Hungarian community.(7) An ordained minister of the United Church of Christ (Calvin Conference), son of a well-respected Hungarian builder, professor of history at Elmhurst College and Rutgers, Professor Molnar has played a leading role in several research projects and was instrumental in establishing the Hungarian Studies program at Rutgers University. His credibility and integrity have worked for the benefit of this non-profit organization "devoted to furthering the understanding and appreciation of the Hungarian cultural and historical heritage in the United States" [American Hungarian Foundation website] and internationally. From its inception, the ambitious goals of the Foundation extended far beyond establishing an academic program and included plans for a new building to house research facilities and to serve as a repository for American Hungarian treasures.

The history of the library and museum collection also goes back to Elmhurst College. In the early 1940s, the collection of the Hungarian Department was maintained by the college's library, and donations and purchases soon increased the number of titles. When the Franklin and Marshall College donated its entire Hungarian collection to Elmhurst, the library's holdings came to total approximately 3,000 volumes. The newly-established American Hungarian Studies Foundation put the library and museum program at the top of its priority list [Kovács 2007: 116]. When the Foundation relocated to New Brunswick in 1959, the collection moved to Rutgers University. In 1965, when the Foundation found a new home at 177 Somerset Street, part of the collection was moved to this new location. The collection can now be found in the impressive building of the Hungarian Heritage Center at 300 Somerset Street, which also houses the Archives, Museum, and Gift Shop.

Designed by architect László Papp, a Hungarian American 56-er, the Hungarian Heritage Center in New Brunswick is a Hungarian American dream come true. Since 1989, the building has been the home of a library containing more than 60,000 volumes. Average yearly growth is 1,750 titles written in Hungarian. The subjects covered are diverse, though the primary focus is on Hungarian immigration history. Complementing this collection is an extensive and diverse archival collection of rare books, manuscripts, and other documents of historical 
significance. The Library functions as an affiliate library of Rutgers University Libraries. Its holdings are integrated into the university library's Online Public Access Catalog (OPAC), which feeds data into national catalogs, such as OCLC WorldCat. This makes the collection accessible to the academic research community worldwide.

The scope of the collection is best described by the stated purpose of the Foundation, namely to preserve and document contributions to Hungarian culture and American Hungarian life. Covering academic disciplines such as history, literature, sociology, linguistics, European Studies, Hungarian Studies, the library constitutes the major research and reference resource in Hungarian Studies in the United States. A 7.5 by 11 centimeter bookplate is applied to each volume in the collection. The bookplate is a facsimile of the George Washington Award, presented each year by the American Hungarian Foundation in recognition of outstanding contributions to Hungarian culture or the Hungarian community by a person of Hungarian background or a non-Hungarian. The print collection serves scholars and students from any area of humanities conducting research on Hungarian or comparative Eastern and Central European subjects (e.g., art, history, literature, linguistics, sociology). In addition to the scholarly audience, the Foundation attracts a broader community of users, ranging from recent immigrants to second- or third-generation Hungarians of all ages. They are interested in a variety of topics, such as genealogy, Hungarian embroidery, immigration to the United States, American Hungarian organizations in a given geographical location, or even recipes and sources of authentic Hungarian food. Library users work on dissertations, scholarly publications, term papers, books, or articles not only on Hungarian topics, but also on related subjects such as folklore in the Carpathian basin, genres of East European poetry, the history of Radio Free Europe, or emerging economies, to name but a few topics.

The Archive of the American Hungarian Foundation has a unique document collection of Hungarian and American Hungarian materials. It is comprised mostly of bequests of individuals and organizations with Hungarian background and can be considered a collection of exceptional historical value, providing primary data pertinent to a broad range of scholars. Examples of research resources on contemporary history include the documents from Camp Kilmer and the United Nations and newspaper clippings on the 1956 revolution. Access to the archives is limited to scholars. The Archive hosts the Bethlen Collection, a major collection of Hungarian documents of the past two centuries (8) 
The Library and Archives of the American Hungarian Foundation has diverse resources, while its subject scope defined by its collection development policies and its main source of acquisitions: donations by individuals and organizations. The collection features an enormous variety of materials with one common characteristic: every title in the library and the archive is associated with Hungary or Hungarians. The contributors to the collection vary. They include famous writers, poets, and scholars, clergy, craftsmen, businessmen, common people, and technicians. Contributors also include amateur media creators who recorded audio and other media. There are submissions from painters and other artists, whose artwork was exhibited and then preserved on video tapes or in catalogs.

The collection is not limited to a particular domain, style, format, or genre. It covers well-known literary works, collected works of one particular author, individual pieces, yearbooks and calendars, dictionaries, art books, reference books, small print, songbooks, scores, maps, memoirs, diaries, and guide books. Also included are such official and personal documents as letters, postcards, notes, manuscripts, photos, and sound and video recordings. Two noteworthy examples are handwritten letters by $19^{\text {th }}$-century Hungarian political leader Lajos Kossuth and documents related to classical composer Zoltán Kodály. Both are highly cherished assets of the collection. Dates of publication or creation range from the $15^{\text {th }}$ century to the present. Most items were published in or originate from one of two countries: the United States and Hungary, although there are titles from the many other countries in the world where Hungarians live.

As for display medium, the majority of the library collection is printed material, such as books, journals, and newspapers. In terms of periodicity, monographs are predominant. Periodicals tend to be represented by individual issues, since the foundation does not have subscriptions or standing orders. Other formats can also be found, namely video tapes in both NTSC and PAL format, DVDs, vinyl records, audio tapes, audio CDs, microforms, photographic and painted material, handwritten manuscripts, maps, and scores. Some materials can be found in electronic format and is also available online.

A sample of recent publications based on research conducted in the AHF Library and Archives indicates the scope, depth, and caliber of research.(9)

John Matthews wrote a comprehensive monograph on the Hungarian Revolution of 1956 [Matthews 2007]. A tribute to the 
monuments of 1956 was written by Beverly James [James 2008]. The library also helped with creative works, namely Pat Valdata's novel [Valdata 2008], and film director Péter Forgács brand new documentary entitled Hunky Blues.

\section{Hungarian resources for folklore research at AHF Library and Archive}

The interest in folklore research on the part of Hungarian Americans goes back to the beginning of the twentieth century, when the Hungarian American folk song was described as follows:

In the Hungarian-American folk-song, we find traces of the keen disappointment which the immigrant feels on his arrival in the Castle Garden Immigration bureau. The strange language, unheard-of customs, callous treatment and ever-present uncertainty are expressed in sad stanzas. Of all his sentiments, his longing for the old country and his fireside seem to furnish most of the themes for his new songs [Ware 1916: 434-441].

Folklore as a means of constructing and maintaining national identity among Hungarian Americans was also studied [Degh 1984: 187-200].

As a result of Hungarians migrating and re-migrating, Hungarian folk traditions in the homeland were also influenced by new, American customs, as the migrant workers brought back and implanted new ideas, concepts, and techniques. Hungarian folk songs with American elements were collected in the Northeast regions of Hungary which produced the largest numbers of immigrants. These songs obviously had their roots in "America," and were composed and sung during the sojourn in America [Gunda 1970: 406-416]. Nowadays the Internet, the best carrier of contemporary urban legends, also easily crosses the borders of the two countries and the so-called "Hungarian Suicide Song" has gained a life of its own in both environments. According to this legend, the 1933 song by Rezső Seress called Gloomy Sunday has inspired people to commit suicide for decades [e.g., Coleman 2004: 182]. In addition to the various recent renditions available on YouTube, it is the topic of chat rooms and message boards all over the Internet.

In addition to its impressive music collection including recordings of folk and dance music, as well as sheet music and handwritten copies of folk music, the library offers a wide variety of traditional resources for folklore researchers in terms of topics, formats, and geographical locations. Photos, letters, soundtracks, vinyl records, video tapes, and microfilms are just a few of the formats that complement the periodical collection, monographs, memoirs, and reference books. Researchers will find ample material here on folk customs, voice and instrumental folk 
music, dance, and even dolls depicting folk costumes from different Hungarian-speaking regions of the Carpathian basin such as Transylvania, Vojvodina, and the Sub-Carpathians. The Library and Archives is probably the best repository for original resources on Hungarian American immigrants and should be the research destination of both linguists and folklorists. The present exhibit of Hungarian Folk Art Collection (Magyar Népmüvészet), on display through February 28, 2010, features furniture, pottery, homespun textiles, and embroidery. The exhibit debuts the museum's folk art collection, including three recent major gifts and promised gifts.

The strong ties that Hungarian Americans feel to religion and religious community make the Bethlen collection a particular prize of the Archive. The Bethlen Home was founded in Ligonier, Pennsylvania in 1895 by the Hungarian Reformed Church. It served as a home for orphans and later became a retirement home. Its entire document collection was deposited in the archives. Archival processing has been completed and a finding aid is also available in EAD (Encoded Archival Description). With its 113 cubic foot content, the collection contains administrative records of the Bethlen Home, as well as official documents donated by Protestant churches and various religious, fraternal, political and cultural organizations. These materials include registers, ledgers, budgets, administrative files, annual reports, minutes, correspondence, circulars, official programs of festive occasions, conventions, and other events, orders of worship, official publications, project plans, documents on public relations and lobbying activities, constitutions, by-laws and photographs. The annual Bethlen Calendar is a treasure of Hungarian folk traditions.

\section{Beyond culture}

The Library and Archives of the American Hungarian Foundation also documents the Foundation's history, activities, and significance in Hungarian American culture. As a cultural organization, it sets an excellent example of success, including fundraising experience and best practices. It should be especially noted for its inclusivity: it does not exclude any groups. With its historical ties to the Rutgers University community, it also contributes to the development of a college program in a minority language and culture, which draws heavily on local resources. Reaching out to the community at large, it aims to serve researchers from the academic community, as well as independent scholars and K-12 students, including New Jersey ethnic groups. With 
the President of the AHF serving on boards and advisory committees, the history of the foundation proves that "there is a way to communicate to the community and to strengthen ties both ways" [Hajnal Ward and Csürös Clark 2009]. Because of the work of the American Hungarian Foundation, a global community interested in Hungarian matters can benefit from an outstanding set of resources.

\section{NOTES}

1 As noted by the most accomplished expert on Hungarian libraries in the United States, Ilona Kovács of the National Széchényi Library, who was instrumental in establishing the Hungarica WWW, among others. For more, see references.

2 For more, see Tamas [Tamas 1997: 615-634], who, based on the New Brunswick area Hungarians, describes Hungarian organizations by types throughout the history of Hungarian immigration).

3 There have been numerous studies examining the various waves of immigration. For the most comprehensive history of the topic, please cf. Puskás 2000.

4 Many of the 56-ers made a significant difference in Hungarian culture and politics by their voluntary mission in the new country to preserve the Hungarian heritage. An organization made up of Rutgers alumni must be noted for its contributions. For more, see Nagy 2000.

5 A case study of 120 years of Hungarians in New Brunswick analyzes the life of Hungarian immigrants in the area from a sociological perspective in Hungarian (Smik 2004: 65-88). The role of New Jersey Hungarians in a more global, transnational ethnic network is presented also using New Brunswick as an example (Tamás 1997).

6 The preferred term is "American Hungarian" over the more typical "Hungarian American". By putting American first, the goal is to put the emphasis on the Hungarian, with American serving as an adjective [Woznick 1995: 462]

7 The history of the American Hungarian Foundation is well documented by their 50th anniversary publication, including short biographies of their leaders [Kovács 2007].

8 The Bethlen Collection was cataloged and processed for preservation recently by a visiting Fulbright scholar, Dr. Ilona Kovács, retired head of the National Széchényi Library of Hungary. A search aid is soon to be available online. The cooperation between the AHF Library 
and the National Széchényi Library is also exemplary in the preservation of cultural heritage.

9 The library operates as a single-librarian facility. Our research was also assisted by the librarian-archivist, Margaret Papai.

\section{BIBLIOGRAPHY}

Coleman, Loren. 2004. The Copycat Effect: How the Media and Popular Culture Trigger the Mayhem in Tomorrow's Headlines. New York: Paraview Pocket Books.

Degh, Linda. 1984. "Uses of Folklore as Expressions of Identity by Hungarians in the Old and New Country," Journal of Folklore Research 21(2-3): 187-200.

Degh, Linda. 1966. "Approaches to Folklore Research Among Immigrant Groups," The Journal of American Folklore 79(314) (Oct. - Dec.): 551-556.

Gellén, József. 1985. "Acceptance and Rejection: Proto-ethnicity in Some Hungarian-American Writings," MELUS 12(4): 25-35.

Gunda, Bela. 1970. "America in Hungarian Folk Tradition," The Journal of American Folklore 83(330): 406-416.

Hajnal Ward, Judit and Sylvia Csürös Clark. 2009. Unpublished Interview with August J. Molnar on the History of the American Hungarian Foundation.

Home Page of the American Hungarian Foundation: http://ahfoundation.org. (Consulted 14 May, 2009).

James, Beverly A. 2008. Monuments to the Revolution: HungarianAmerican Tributes to 1956. Author's publication. [s.1.]

Kovács, Ilona. 1987. "Problems and Patterns in the Development of Library Services for ethnic Hungarians in the United States in the First Decades of the 20th Century," Hungarian Studies 3(1-2): 248260.

Kovács, Ilona and Faragó Lászlóné, (eds.). 1994. Külföldi Hungarikaanyagot örzö magyar könyvtárak címjegyzéke. [Foreign Hungarica to be found in Hungarian Libraries]. Budapest: OSzK.

Kovács Ilona. 1998. "Az amerikai egyházi kiadványok" [American religious publications] in A magyar müvelödés és a kereszténység. A IV. Nemzetközi Hungarológiai Kongresszus előadásai. RómaNápoly, 1996. szeptember 9-14. III. [Proceedings of the $4^{\text {th }}$ International Congress on Hungarian Studies, Rome - Naples, 9-14 September, 1996] Szerk. Jankovics József, Monok István, Nyerges 
Judit. Budapest-Szeged: Nemzetközi Magyar Filológiai Társaság Scriptum Rt. 1868-1884.

Kovács, Ilona, (ed.). 2007. The Hungarian Legacy in America: The

History of the American Hungarian Foundation, the First Fifty

Years, 1955-2005. New Brunswick, NJ: American Hungarian

Foundation.

Kovács, Ilona. 2008. “Az amerikai magyar könyvtári gyüjtemények, mint az etnikai könyvtári gyüjtemények típusai” [American Hungarian Library Collections as Types of Ethnic Library Collections], Nyelvünk és kultúránk 3: 25-36.

Matthews, John P. C. 2007. Explosion: The Hungarian Revolution of 1956. New York, NY: Hippocrene Books.

Nagy Károly 2000. Emigránsok küldetésben - A Magyar Öregdiák Szövetség-Bessenyei György Kör, Hungarian Alumni Association, 1960-2000 [Emigrants in a Mission - Hungarian Alumni Association-Bessenyei György Circle]. New Brunswick, NJ, Debrecen: Csokonai.

Puskás, Julianna. 2000. Ties that Bind, Ties that Divide: 100 years of Hungarian Experience in the United States. Ellis Island Series. New York: Holmes \& Meir.

Smik, Csaba Ferenc. 2004. "Valahol otthon lenni. Tanulmány az amerikai magyar emigránsok százhúsz évérõl - New Brunswick példáján keresztül" [To be at Home. Study of 120 Years of Hungarian Life in America: The Case of New Brunswick], Regio (1): $65-88$.

Tamas, Tamas. 1997. "Evolution of a Global Community: New Jersey Hungarians in a Trans-National Ethnic Network," International Journal of Politics, Culture \& Society 10(4): 615-634.

Urbanic, Alan and Beth Feinberg. 2004. "A Guide to Slavic Collections in the United States and Canada," Slavic and East European Information Resources 5(3/4): 1-193.

Valdata, Pat. 2008. The Other Sister. Austin, TX: Plain View Press.

Várdy, Steven Béla. 2001. "Image and Self-Image among Hungarian-

Americans since the Mid-Nineteenth Century," East European Quarterly 35(3): 309-342.

Ware, Helen. 1916. "The American-Hungarian Folk-Song," The Musical Quarterly 2(3): 434-441.

Woznick, L. A. 2004. “The Cover” Libraries \& Culture, 39(4), 461-466. 